\title{
A genomic view of mRNA turnover in yeast
}

\section{Génomique du rechangement de l'ARNm chez la levure}

\author{
José E. Pérez-Ortín ${ }^{\mathrm{a}, *}$, Antonio Jordán-Pla ${ }^{\mathrm{a}}$, Vicent Pelechano ${ }^{\mathrm{b}}$ \\ ${ }^{a}$ Departamento de Bioquímica y Biología Molecular, Facultad de Ciencias Biológicas, Universitat de València, Dr. Moliner 50, 46100 Burjassot, Spain \\ ${ }^{\mathrm{b}}$ European Molecular Biology Laboratory, Meyerhofstrasse 1, Heidelberg, Germany
}

\section{A R T I C L E I N F O}

\section{Article history:}

Received 5 November 2010

Accepted after revision 17 March 2011

\section{Keywords:}

Run-on

Gene expression kinetics

Transcription rate

mRNA stability

ChIP-chip

Mots clés :

Run-on

Cinétique de l'expression génique,

Taux de transcription

Stabilité des ARNm

ChIP-chip

\begin{abstract}
A B S T R A C T
The steady-state mRNA level is the result of two opposing processes: transcription and degradation; both of which can provide important points to regulate gene expression. In the model organism yeast Saccharomyces cerevisiae, it is now possible to determine, at the genomic level, the transcription and degradation rates, as well as the mRNA amount, using DNA chip or parallel sequencing technologies. In this way, the contribution of both rates to individual and global gene expressions can be analysed. Here we review the techniques used for the genomic evaluation of the transcription and degradation rates developed for this yeast, and we discuss the integration of the data obtained to fully analyse the expression strategies used by yeast and other eukaryotic cells.

(C) 2011 Académie des sciences. Published by Elsevier Masson SAS. All rights reserved.

R É S U M É

Le taux de l'ARNm est maintenu à l'équilibre grâce à deux processus antagonistes : la transcription et la dégradation. Ces deux mécanismes sont cruciaux pour réguler l'expression des gènes. Dans l'organisme modèle Saccharomyces cerevisiae, il est maintenant possible de déterminer, au niveau génomique, les taux respectifs de transcription et de dégradation, ainsi que la quantité d'ARNm présente, en utilisant les puces à $\mathrm{ADN}$ ou le séquençage en parallèle. De cette manière, il est possible de connaître la contribution de chacun de ces processus en analysant le niveau d'expression des gènes individuellement et globalement. Nous présentons et comparons dans cet article les techniques utilisées pour évaluer les taux respectifs de transcription et de dégradation des transcrits de cette levure. Nous discutons la possibilité de l'utilisation des données obtenues pour analyser en profondeur les stratégies d'expression employées par la levure ainsi que par d'autres cellules eucaryotes.
\end{abstract}

(c) 2011 Académie des sciences. Publié par Elsevier Masson SAS. Tous droits réservés.

\section{Introduction}

Eukaryotic gene expression is a complex process (Fig. 1) that is regulated at transcriptional and post-transcriptional steps. It involves successive, but overlapping and interrelating, steps that are subjected to regulation and quality

\footnotetext{
* Corresponding author.

E-mail address: jose.e.perez@uv.es (J.E. Pérez-Ortín).
}

controls. The transcription rate (TR) is the rate at which mature molecules in the cytoplasm appear, while the rate at which RNA polymerase II transcribes a gene can be named "nascent" TR. Both rates describe the number of mRNA molecules being produced. Nonetheless, nascent TR is always higher than TR because, logically, many molecules are degraded during elongation or before leaving the nucleus. The actual proportion of this apparently unsuccessful transcription is currently unknown. 

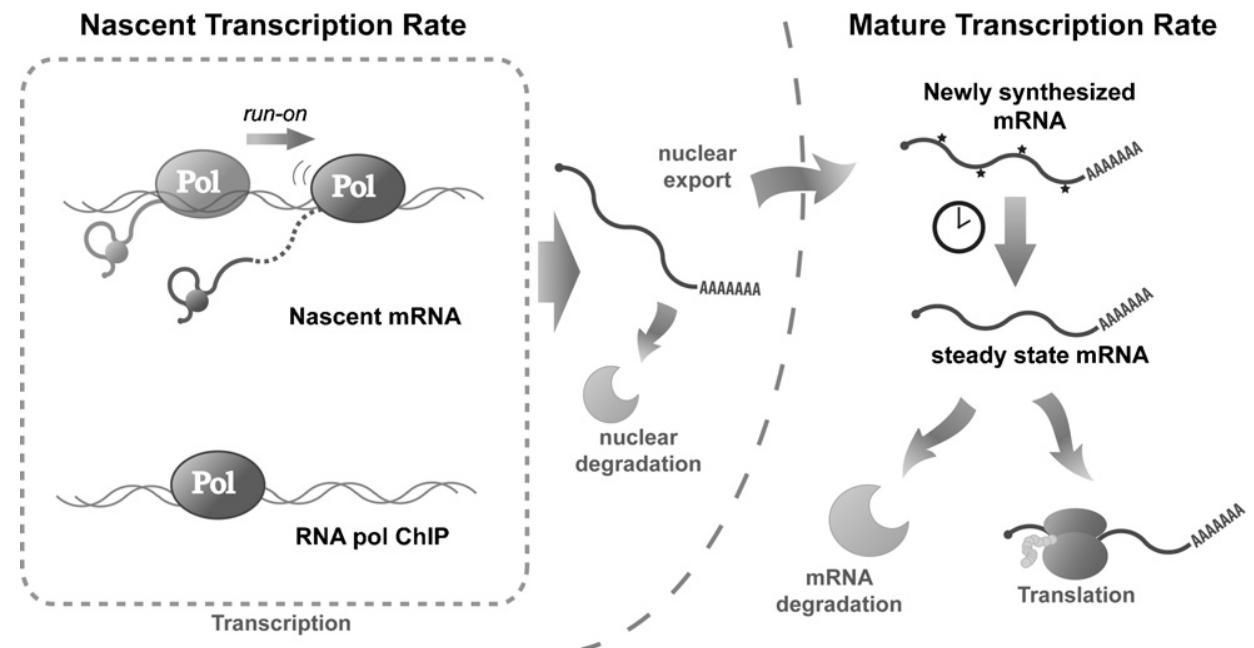

Fig. 1. Methods to study the transcription rate at genomic scale. mRNA is transcribed, processed and transported from genes to the cytoplasm. The TR can be measured along all the different steps. For the direct measurement of the TR (nascent TR, left-hand side of the figure), it is possible to measure the physical association of polymerase (RNA pol ChIP), the presence of nascent transcripts or the elongation activity by run-on. It is also possible to measure the newly synthesised mRNA or to estimate mature TR either by pulse-labelling experiments or indirectly by assuming a dynamic equilibrium between its transcription (TR) and degradation (DR) rate (right-hand side of the figure).

mRNA molecules do not live forever. This relative instability is the result of both the degradation of erroneous molecules and the biological need for mRNA turnover, which allows cellular re-adaptation to changing environments. The degradation of mature and correct mRNA molecules is conducted by specialised exonucleases and companion proteins (see Ref. [1] for a review). The mRNA degradation rate (DR) is regulated and controlled, and plays an important role at the cytoplasmatic mature mRNA level, as with the TR. Each mRNA species has its own characteristic stability (RS). Therefore, the amount (or concentration) of an individual mRNA (RA) is the balance between these processes: TR and DR.

When the environment does not change, it is logical to assume that most genes have a constant RA and are, therefore, in steady-state conditions. Thus in this situation, the TR and DR for each mRNA are equal. In other situations where the RA varies, this change could be due to variations in the TR, the DR, or in both. Traditionally, transcriptional responses have been studied only as changes at the RA level both on a single gene scale and on the genomic scale without differentiating the respective contributions of the TR and the DR. These approaches have been reviewed many times (e.g., [2]), whereas the genomic study of RS and the TR is more recent.

The use of genomic techniques to evaluate RA, TR and RS allows the study of general rules for the kinetic regulation of RA for groups of genes [3,4]. Moreover, the serial profiling of kinetic parameters during gene expression helps to identify functionally-related genes that could use common regulatory pathways at various levels in eukaryotic gene expression. The best-suited organism for genome-wide expression analyses is the yeast Saccharomyces cerevisiae. For this reason, this review focuses on the genome-wide protocols and data for RS and TR estimations with this yeast, and also on the general conclusions on yeast transcription and mRNA turnover drawn from them.

\section{Methods for the genomic evaluation of transcription rates}

Transcription rates can be defined as the number of mature mRNA molecules produced in a cell by a unit of time. However, the definition of a "mature mRNA" is flexible because mRNA is subjected to many maturation steps (Fig. 1); and several different populations of mRNA exist in the cell. Thus, the measured transcription rate can change according to the mRNA subpopulation being studied.

Several techniques have been developed to measure transcription (Fig. 1), some rely on the direct measurement of the transcriptional process, while others use indirect measures to mathematically derive the TR (see below). Although all the direct methods study the same process, the different experimental approaches used can produce slightly different results. This is due to not only the possible methodological biases of each technique, but also biological differences depending on the particular step of the transcription process being measured.

Most TR estimation techniques available do not directly measure the number of mRNA molecules produced in a given time, rather they determine the number of RNA polymerase II molecules present in a gene to compute nascent TR (Fig. 1, left-hand side). All these methods rely on the assumption of a constant RNA pol II elongation rate; however, this is a drawback because it is well-established that the elongation rate is subject to regulation [5].

The simplest approach is the use of the measurement of the polymerase bound to each gene as an indicator of its transcription level. This can be done using the well-known Chromatin immunoprecipitation techniques (ChIP) in their different variants, e.g., ChIP-chip [6,7] and ChIP-Seq [8]. When using an antibody against RNA pol II, ChIP-chip provides a measurement of RNA pol II density. The use of different antibodies can add selectivity to the type of 


\begin{tabular}{|c|c|c|c|c|c|c|c|c|}
\hline \multicolumn{9}{|l|}{ Transcription rates } \\
\hline \multicolumn{3}{|l|}{ Advantages } & \multicolumn{4}{|l|}{ Limitations } & & \multirow{2}{*}{$\begin{array}{l}\text { References } \\
{[3,46,50]}\end{array}$} \\
\hline \multicolumn{2}{|l|}{$\begin{array}{l}\text { Radioactive Run-on-based } \\
\text { methods (GRO) }\end{array}$} & $\begin{array}{l}\text { Direct estimation of elongating } \\
\text { RNA pol II densities } \\
\text { Nascent TR }\end{array}$ & \multicolumn{2}{|c|}{$\begin{array}{l}\text { Average TR estimation } \\
\text { throughout } \\
\text { the coding region }\end{array}$} & \multicolumn{2}{|c|}{$\begin{array}{l}\text { Assumes a constant } \\
\text { elongation rate for } \\
\text { RNA pol II }\end{array}$} & & \\
\hline $\begin{array}{l}\text { Non-radioactive } \\
\text { Run-on-based } \\
\text { methods. }\end{array}$ & $\begin{array}{l}\text { Allows for tiling array and } \\
\text { HTS single nucleotide } \\
\text { resolution }\end{array}$ & $\begin{array}{l}\text { Direct estimation of elongating } \\
\text { RNA pol II densities } \\
\text { Nascent TR }\end{array}$ & \multicolumn{2}{|c|}{$\begin{array}{l}\text { Less sensitive than radioactive } \\
\text { methods. May require nascent } \\
\text { RNA purification }\end{array}$} & \multicolumn{2}{|c|}{$\begin{array}{l}\text { Assumes a constant } \\
\text { elongation } \\
\text { rate for RNA pol II }\end{array}$} & & $\begin{array}{l}\text { [17] Not yet } \\
\text { implemented } \\
\text { for yeast }\end{array}$ \\
\hline $\begin{array}{l}\text { Chromatin } \\
\text { immunoprecipitation- } \\
\text { based methods }\end{array}$ & $\begin{array}{l}\text { Different antibodies } \\
\text { allow the differentiation } \\
\text { of RNA pol II states }\end{array}$ & $\begin{array}{l}\text { Direct estimation of RNA } \\
\text { pol II densities } \\
\text { Nascent TR }\end{array}$ & \multicolumn{2}{|c|}{$\begin{array}{l}\text { A fraction of RNA pol II } \\
\text { molecules does not elongate }\end{array}$} & \multicolumn{2}{|c|}{$\begin{array}{l}\text { Assumes a constant } \\
\text { elongation } \\
\text { rate for RNA pol II }\end{array}$} & $\begin{array}{l}\text { Has no strand } \\
\text { specificity. }\end{array}$ & [51] \\
\hline $\begin{array}{l}\text { Indirect estimation from } \\
\text { RA and RS }\end{array}$ & $\begin{array}{l}\text { No need for experimental } \\
\text { protocol }\end{array}$ & Mature mRNA TR & \multicolumn{2}{|c|}{$\begin{array}{l}\text { Error can be increased by } \\
\text { mathematical calculations }\end{array}$} & \multicolumn{2}{|c|}{$\begin{array}{l}\text { Relies on calculations from } \\
\text { other experimental values }\end{array}$} & $\begin{array}{l}\text { Assumes steady- } \\
\text { state conditions } \\
\text { for mRNAs }\end{array}$ & {$[22]$} \\
\hline $\begin{array}{l}\text { In vivo labelling with } \\
\text { UTP precursors }\end{array}$ & Fluorescent labelling & Mature mRNA TR & \multicolumn{2}{|c|}{ Requires a time lapse } & \multicolumn{2}{|c|}{$\begin{array}{l}\text { Requires newly synthesised } \\
\text { RNA purification }\end{array}$} & & {$[20,21,32]$} \\
\hline $\begin{array}{l}\text { Isolation of nascent } \\
\text { chromatin- } \\
\text { bound transcripts }\end{array}$ & $\begin{array}{l}\text { Allows for tiling } \\
\text { array and HTS } \\
\text { single nucleotide } \\
\text { resolution }\end{array}$ & $\begin{array}{l}\text { Direct estimation of } \\
\text { elongating RNA pol II } \\
\text { densities } \\
\text { Nascent TR }\end{array}$ & \multicolumn{2}{|c|}{$\begin{array}{l}\text { Long and demanding protocol } \\
\text { A fraction of RNA pol II } \\
\text { molecules does not elongate }\end{array}$} & \multicolumn{3}{|c|}{$\begin{array}{l}\text { Assumes a constant } \\
\text { elongation rate for RNA pol } \\
\text { II. Requires newly } \\
\text { synthesised RNA purification }\end{array}$} & {$[11,12]$} \\
\hline \multicolumn{9}{|l|}{ mRNA stabilities } \\
\hline Advantages & & & \multicolumn{4}{|l|}{ Limitations } & & References \\
\hline$r p b 1-t s$ & Simple method & & $\begin{array}{l}\text { Involves heat } \\
\text { shock to cells }\end{array}$ & \multicolumn{2}{|c|}{$\begin{array}{l}\text { Difficult to use under } \\
\text { dynamic conditions }\end{array}$} & $\begin{array}{l}\text { Requires a } \\
\text { time lapse }\end{array}$ & $\begin{array}{l}\text { Requires a } \\
\text { mutant strain }\end{array}$ & {$[29,30]$} \\
\hline RNA pol II inhibitors & Simple method & & $\begin{array}{l}\text { Involves toxic } \\
\text { shock to cells }\end{array}$ & \multicolumn{2}{|c|}{$\begin{array}{l}\text { Difficult to use under } \\
\text { dynamic conditions }\end{array}$} & $\begin{array}{l}\text { Requires a } \\
\text { time lapse }\end{array}$ & & {$[30,52]$} \\
\hline $\begin{array}{l}\text { Simple indirect estimation } \\
\text { from RA and TR }\end{array}$ & $\begin{array}{l}\text { No need for experimental } \\
\text { protocol } \\
\text { True in vivo natural } \\
\text { growth conditions } \\
\text { No stress }\end{array}$ & $\begin{array}{l}\text { Instantaneous } \\
\text { measurement }\end{array}$ & $\begin{array}{l}\text { Assumes steady-state } \\
\text { conditions for mRNAs }\end{array}$ & \multicolumn{2}{|c|}{$\begin{array}{l}\text { Error can be } \\
\text { increased by } \\
\text { mathematical } \\
\text { calculations }\end{array}$} & $\begin{array}{l}\text { Relies on } \\
\text { calculations from } \\
\text { other experimental } \\
\text { values }\end{array}$ & & [3] \\
\hline $\begin{array}{l}\text { Indirect estimation from } \\
\text { RA and TR }\end{array}$ & $\begin{array}{l}\text { No need for experimental } \\
\text { protocol } \\
\text { True in vivo natural } \\
\text { growth conditions } \\
\text { No stress }\end{array}$ & $\begin{array}{l}\text { Does not assume } \\
\text { steady-state } \\
\text { conditions for mRNAs }\end{array}$ & & \multicolumn{2}{|c|}{$\begin{array}{l}\text { Error increased } \\
\text { by complex } \\
\text { mathematical } \\
\text { calculations }\end{array}$} & $\begin{array}{l}\text { Relies on } \\
\text { calculations } \\
\text { from other } \\
\text { experimental } \\
\text { values }\end{array}$ & $\begin{array}{l}\text { Needs several } \\
\text { time points. }\end{array}$ & [33] \\
\hline $\begin{array}{l}\text { Pulse and chase } \\
\text { with labelled } \\
\text { UTP precursors }\end{array}$ & $\begin{array}{l}\text { True in vivo natural } \\
\text { growth conditions } \\
\text { No stress }\end{array}$ & \multirow[t]{2}{*}{$\begin{array}{l}\text { Does not assume steady- } \\
\text { state conditions } \\
\text { for mRNAs }\end{array}$} & & \multicolumn{2}{|l|}{$\begin{array}{l}\text { Long and } \\
\text { demanding } \\
\text { protocol }\end{array}$} & $\begin{array}{l}\text { Requires a } \\
\text { time lapse }\end{array}$ & $\begin{array}{l}\text { Needs several } \\
\text { time points }\end{array}$ & $\begin{array}{l}{[19,20] \text { Not yet }} \\
\text { implemented } \\
\text { for yeast }\end{array}$ \\
\hline $\begin{array}{l}\text { Pulse with labelled } \\
\text { UTP precursors }\end{array}$ & $\begin{array}{l}\text { True in vivo natural } \\
\text { growth conditions } \\
\text { No stress }\end{array}$ & & $\begin{array}{l}\text { Assumes steady-state } \\
\text { conditions for mRNAs }\end{array}$ & \multicolumn{2}{|l|}{$\begin{array}{l}\text { Long and } \\
\text { demanding } \\
\text { protocol }\end{array}$} & $\begin{array}{l}\text { Requires a short } \\
\text { time lapse }\end{array}$ & & {$[31,32]$} \\
\hline
\end{tabular}


immunoprecipitated RNA pol II molecules, such as using antibodies against phosphorylated forms of the CTD tail of Rpb1p to select elongating molecules $[9,10]$. However, the ChIP technique also presents several disadvantages (Table 1 ). This technique measures the DNA fragments that are bound by the polymerase. Thus, it is only able to detect the physical presence of the polymerase in that region, and not the activity itself. Moreover, as it studies bound DNA, it cannot provide information about the polymerase orientation.

Another approach, similar to ChIP techniques, relies on the direct detection of nascent chromatin-bound transcripts. This can be done because the high stability of ternary complexes formed in vivo between genomic DNA, RNA pol II, and nascent RNA, allows its study either by means of co-immunoprecipitation of RNA with RNA pol II antibodies without the need for crosslinking [11] or by purification of chromatin and, then, of the nascent RNA bound to it [12]. It has the advantage of measuring only those polymerases that have a nascent transcript hanging from them, thus providing a more direct measure of transcriptional activity. However, the fact that one RNA polymerase is associated with an mRNA does not necessarily imply that it is transcriptionally active as the polymerase can also be backtracked or paused [13].

The standard approach to directly quantify the density of elongating RNA polymerases is the transcription run-on assay (TRO) [13]. This method is based on allowing the extension of nascent transcripts by cellular RNA polymerases in the presence of labelled (usually radioactive) nucleotides. Afterwards, RNA is extracted and nascentlabelled transcripts are hybridised to a single filter containing multiple gene probes (Genomic Run-on, GRO), allowing quantitative comparisons. GRO takes advantage of the fact that not every polymerase sitting on DNA is able to perform run-on in the presence of labelled nucleotides to discriminate between actively elongating polymerases and polymerases stopped without mRNA or unable to elongate for some other reason (e.g. backtracking). Under the assumption that RNA polymerases elongate at a constant rate, the quantification of their density provides a TR measure at the time of RNA labelling [13].This technique has been applied to $S$. cerevisiae to perform accurate kinetic measures of TR in both standard growing conditions [4,14], and in plenty of different stress responses $[3,15,16]$. One of the advantages of yeast is that the GRO assay can be performed on whole cells, which allows very rapid and accurate measurements. The possibility of combining non-radioactive labelling (e.g., BrUTP, Biotin-UTP) of run-on samples by high-throughput sequencing [17] or microarray technology $[18,19]$ has only been recently shown.

Another possibility to estimate the transcription rate, which is not based on the study of RNA polymerase presence/activity, is measuring the appearance of a new mRNAs during a known time lapse. This can be done by introducing a labelled nucleotide precursor, for example pulsing with thiouracil [20] or thiouridine [21]. Thiolated RNA is then purified by affinity chromatography and used for microarray analyses. This method is suitable for in vivo applications, and may overcome some of the disadvan- tages of the run-on and ChIP assays in higher eukaryotes to determine transcription rates. As the measured TR needs a long pulse with the precursor, it is not instantaneous, but corresponds to an average in the time-labelling period (Table 1). One important difference between this technique and those based on the detection of RNA polymerase presence/activity is that the required time lapse incubation prevents the detection of transcripts with a very low stability; for instance, cryptic transcripts or other transcripts subject to nuclear degradation.

Finally, the TR can also been calculated indirectly from the knowledge of both the steady-state level of each mRNA species (the transcriptome) and the half-life of those species. This approach needs to assume the existence of a steady-state condition for the transcriptome [4], but the advantage here is that no experimental method is required. However, it does have its drawbacks as it relies on having accurate data for both RA and RS. As RS measures are especially challenging (see below), the use of these data to indirectly compute the TR can imply more experimental errors. Despite these problems, the use of indirect calculations for the TR [22] is widely generalised in the literature $[23,24]$.

\section{Effect of cryptic transcription on different TR measures}

In the last few years, the development of genome-wide techniques has revealed an unexpected complexity among eukaryotic RNA populations in which unstable and overlapping transcripts are more common than previously thought [25]. The function of this plethora of non-coding transcripts is still not well-known [26]. However, these findings evidence that cryptic transcription is a more widespread process than formerly thought. As most of these non-coding RNAs possess a very low stability, the use of methods for measuring nascent TR will reveal the contribution of the cryptic transcription that will not be seen in the measured transcriptome.

One drawback of nascent TR methods is that cryptic transcription is added to the value of the regular one. Therefore, to be able to express the calculated TR, it is necessary to assume that the percentage of cryptic transcription is small. Methods that measure the increase of mature mRNA (e.g., direct pulse-based techniques or indirect TR estimations) are not affected by cryptic transcription. The comparison with methods that measure RNA polymerase activity (e.g., run-on) can provide information about the existence of cryptic transcription, and also about the early post-transcriptional process for the mRNAs pointing at groups of genes that are subject to post-transcriptional regulation (e.g., mRNA maturation and export, etc.) [14].

\section{Methods for the genomic evaluation of mRNA stabilities}

Several different techniques have been used for years for single gene mRNA stability determination in S. cerevisiae (reviewed in $[27,28]$ ); some are not applicable to genomic studies, while others are scalable for genomic 
A

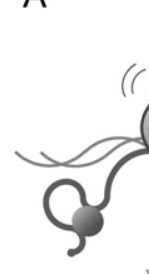

${ }^{\circ}$

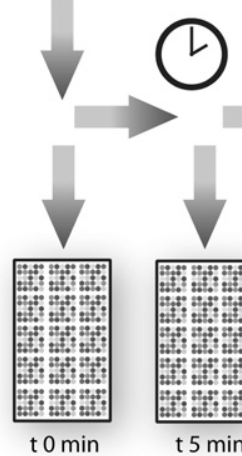

inhibitors

rpb1-1

\section{Pol}

Q

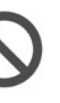

B
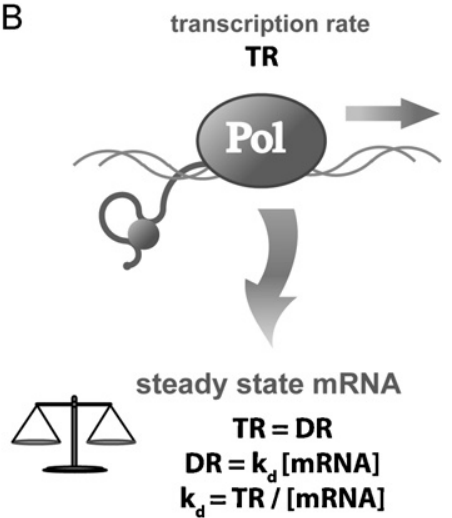

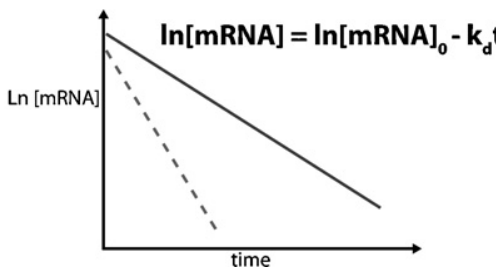

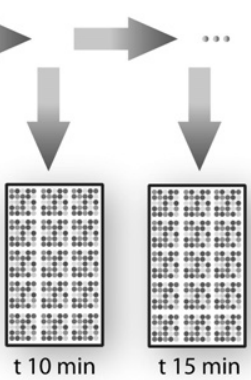

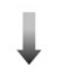

$t_{1 / 2}=\ln \left(2 / k_{d}\right)$
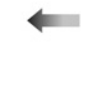

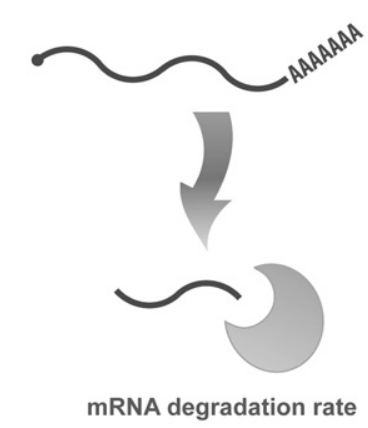

Fig. 2. Methods to study mRNA stability at genomic scale. A) mRNA stability can be measured directly by inhibiting the transcription (using inhibitors or thermosensitive mutants) and then following the disappearance of mRNAs over time. B) Alternatively, it can be also computed indirectly by assuming a steady-state for mRNA production and degradation or by applying kinetic laws for non-steady-state conditions (see the main text).

use. The most used methods are those based on transcription stopping by means of either transcription inhibitors (mainly thiolutin or phenantroline) or the temperature-sensitive mutant $r p b 1-1$ of the largest RNA pol II subunit (RPO21). After the transcription shutoff, the remaining $\mathrm{RA}$ is determined by DNA chip analyses to calculate the decay of every single mRNA over a time interval using the known decay kinetics (Fig. 2). These analyses have established that the mRNA half-lives for yeast range from 3 to $300 \mathrm{~min}$, and that $23 \mathrm{~min}$ is the average time [29]. The yeast genes belonging to the same functional category tended to have similar RS and can be regulated at the mRNA stability level [30].

However, the use of transcription shutoff procedures involves several problems (Table 1). The first is that mRNA half-lives are calculated from the data collected over a considerable time interval (up to $120 \mathrm{~min}$ ). Therefore, the calculated half-life is an average along the time interval. Second, these methods cause a cell stress response due to a temperature shift or a drug addition needed to block transcription, which changes the expression of some genes or possibly alters the mRNA degradation mechanisms during the experiment, as has been shown for human cells in culture (discussed in [31]). Such studies are not appropriate for monitoring stress-induced genes because an instantaneous increase in the mRNA level occurs before the general shutoff, which prevents the decay curve for those mRNAs from being calculated $[29,30]$.
Other direct methods used to calculate RS are those based on the metabolic labelling of mRNA. The most simple method consists in using a pulse with RNA precursors, such as bromouridine [19] or 2,4-dithiouracil [20], which allows to purify nascent RNA with affinity columns. The chase of labelled RNA at different time points after the pulse allows the direct determination of RS from the decay curve. This method has been developed for Toxoplasma gondii [20] and mouse cells [19] in culture because these cells efficiently incorporate those UTP precursors. Recently, it has been shown that it is possible to incorporate 4-thiouridine into yeast cells [32].

To avoid transcription shutoff problems, alternative strategies are needed. One such strategy is based on the properties of the steady-state conditions and on chemical kinetics laws. Since the degradation rate follows first-order kinetics $\left(\mathrm{DR}=k_{d} \mathrm{RA}\right)$ in steady-state conditions $(\mathrm{TR}=\mathrm{DR})$ :

$\mathrm{TR}=k_{d} \times \mathrm{RA}$

In most papers, mRNA stability is given as a half-life (referred to here as RS) instead of $k_{d}$, therefore:

$\mathrm{RS}=\ln 2 \times \mathrm{RA} / \mathrm{TR}$

This allows us to calculate values for either the TR or RS whenever the respective values and RA are available. Experimentally determined TR values are needed for RS determination (see the previous section). This method 
offers the advantage of not needing a time lapse in which circumstances may vary. However, it has two important drawbacks: it is necessary to assume steady-state conditions for each mRNA species (which is not usually easy to demonstrate [4]), and it may imply the mathematical amplification of experimental errors (Table 1).

Since steady-state conditions cannot be guaranteed for most genes in many circumstances, a different mathematical approach can be applied. In those cases where Eq. (1) is not operational, a differential equation could be used:

$$
\begin{aligned}
& {\left[\left(\mathrm{TR}_{2}-\mathrm{TR}_{1}\right) /\left(t_{2}-t_{1}\right)\right]-\mathrm{TR}_{2} \cdot k_{d}+\mathrm{RA}_{2} \cdot k_{d}^{2}} \\
& =\left[\left[\left(\mathrm{TR}_{2}-\mathrm{TR}_{1}\right) /\left(t_{2}-t_{1}\right)\right]-\mathrm{TR}_{1} \cdot k_{d}+\mathrm{RA}_{1} \cdot k_{d}^{2}\right] \\
& \quad \cdot \exp \left[-\left[k_{d} \cdot\left(t_{2}-t_{1}\right)\right]\right]
\end{aligned}
$$

(see Ref. [33] for details). We have used this approach in some experiments in which yeast cells were subjected to osmotic, oxidative or heat stress, and have found that most genes undergo changes in their mRNA stability during the stress response $[15,16,34]$. This method requires complex calculations, thus the experimental error is more prone to being mathematically amplified. However, it is possible to draw conclusions for the behaviour of the groups of related genes.

Another possibility is labelling cells in culture with a pulse of labelled UTP precursors and isolating a single time point after it. The comparison of nascent mRNA with total (mature) mRNA isolated from the same sample allows the determination of the incorporation rate of nascent mRNA into the mature mRNA pool and to, therefore, assume steady-state conditions to mathematically calculate the RS for it (reviewed in [20]). An application of this method, known as Dynamic Transcriptome Analysis (DTA) has been recently developed for yeast [32]. DTA has estimated that most transcripts have a very low synthesis rate per cell and cell cycle, and that their half-lives have a median of about $11 \mathrm{~min}$. Interestingly, this disagrees with the median halflife, 23 min, calculated by direct methods [29]. This may mean that the direct estimations are affected by the stress caused by stopping transcription (see above). A drawback of this method is that the time for pulse-labelling the cells (from few minutes in yeast to several hours in higher eukaryote cells) limits its use for fast-changing situations.

\section{The steady-state transcriptome: a snapshot of yeast transcription}

By using the GRO method, we have found that the median TR in yeast genes is about 7 mRNAs/h; $90 \%$ of them have TRs of between 2.33 and $29.7 \mathrm{mRNAs} / \mathrm{h}$, and the total transcription for RNA pol II in a yeast cell growing in standard conditions is about 60,200 mRNAs/h [14].

Gene functional groups tend to have similar TRs. Histone genes are the highest transcribed genes with a median TR of $206 \mathrm{mRNAs} / \mathrm{h}$, if we take into account they are only transcribed during the $S$ phase. The statistical distribution shows that less than $1 \%$ of yeast genes have more than one molecule of elongating RNA pol II/gene. Therefore, we can state that productive transcription on a yeast gene is a rare phenomenon in an actively growing cell. In any case, the existence of "unproductive transcription" (cryptic tran- scription, see above) inside and outside coding regions $[25,35,36]$ may alter these figures. Therefore, we calculate that about 690-1200 RNA pol II molecules actively transcribe in a snapshot of an average cell during exponential growth in YPD medium [14]. On the other hand, as our data are population averages and since cell populations tend to be quite variable [37], it is most likely that some individual cells in some genes have higher densities than others.

The number of mRNA molecules in a yeast cell has been determined by different methods. Published values oscillate between 15,000 [38] and 60,000 [37]. When an intermediate value is used, 26,000 molecules/haploid cell, the turnover of the global yeast transcriptome in a exponentially growing cell is about 2-3 times per generation. This is obviously an average of very different turnovers for different mRNA species. Some are replaced many more times per cycle. Others, however, can be inherited from the cell mother, or even from grandmothers [39].

\section{The changing transcriptome: strategies for mRNA turnover in response to stress}

The most interesting application for the kinetic study of gene expression is the case of changing environments. The GRO method allows the instantaneous determination of the TR and RA and, by mathematical approaches (see above), the determination of RS values for mRNAs. Following this strategy, we have studied yeast responses to change in carbon sources [3], and in oxidative [15], osmotic [16] and heat [34] stresses. In all cases, we have found that changes in both the TR and RS contribute to changes in RA for most stress-responsive genes. In many cases, responses are homodirectional, i.e., increases in the TR together with increases in RS (decreases in $k_{d}$ ) bring about an increase in RA for stress-induced genes and, correspondingly, the opposite applies to stress-repressed genes (mostly translation-related genes). In those cases, the TR seems to be the main factor that determines changes in RA [3,34]. However, there are interesting differences in RS profiles, which indicate that changes in mRNA stability are used to finely tune the response. In other cases, changes in RS partially compensate changes in the TR. For instance, in changes in glucose for galactose, a general downshift in the TR is compensated by general mRNA stabilisation which keeps the mRNA concentrations relatively high while cells readapt to the new metabolism [3]. This case illustrates the possibility of changes in RS for the purpose of saving mature mRNAs, even when they are not being translated [40] for future use. Other authors [41] have used their own and our published data on oxidative stress [15] to reveal that stressinduced genes display a paradoxical decrease in RS. This has been interpreted as a way to speed the transcriptional response because unstable mRNA is able to change its RA faster in accordance with chemical kinetics laws [33]. Another interesting application for the kinetic study of gene expression is the use of TR changes to cluster the genes during a stress response. This is a better method for the determination of gene regulons than RA profiles [42] because, as stated above, the transcription factors controlling gene transcription and RA profiles depend not only on 
TR changes, but also on RS changes. RS profiles, on the other hand, can be used to look for RNA binding proteins (RBP) which could be responsible for changes in the stability of their target mRNAs $[43,44]$. We have used these profiles during the heat stress response to find the putative RBPs involved in the regulation of mRNA stabilities in some gene groups [34].

For the first time in any organism, the existence of genomic data for the three variables involved in transcription (RA, TR and RS) in yeast allows a detailed study of the strategies followed by yeast genes to cope with the functions they perform. However, mRNA should be translated into protein, which can also be controlled at the stability level. A comprehensive study of gene regulation should use all six variables in gene expression (TR, RA, RS, translation rate, protein amount and protein stability) throughout a changing physiological situation to evaluate the respective contributions of each one to the expression of each gene. Currently, however, protein variables are only known for a single condition: exponential growth in a complete medium. Nevertheless, the study of steady-state conditions may shed light on the strategies that genes may adopt during physiological changes. We have used published protein variables data, together with those of the mRNA variables, to evaluate the general strategies of yeast genes under this steady-state condition. We have found that functionally-related genes follow similar strategies. We have also drawn the conclusion that regulation at the transcription level is quantitatively more important than at the translation level, and that RS plays a distinctive role for gene expression: to modulate the response speed [45]. Once again, this highlights the importance of the kinetics in gene expression strategies.

\section{Concluding remarks: studies in other organisms}

Although techniques for the genomic evaluation of RA have been widely developed, the state of the art for the TR and RS in organisms other than $S$. cerevisiae is much less advanced. mRNA half-lives are short for free-living organisms (a few minutes), and are much longer for complex eukaryotes (up to many hours). For TR determination, run-on techniques are only possible in eukaryotes. In higher eukaryotes, TRO should be performed on isolated nuclei, causing a lag between the actual physiological state of the cell and the capture of nascent RNA. Moreover, studies in which a comparison between RAs and TRs has been made offer only qualitative results [46-50]. Thus, yeast $S$. cerevisiae is currently the best-suited organism to perform a genomic view of mRNA turnover.

\section{Disclosure of interest}

The authors declare that they have no conflicts of interest concerning this article.

\section{Acknowledgements}

The authors are grateful to the members of their laboratories for discussion and support and to Dr Anick
Pierce for her French translation. V.P is supported by an EMBO fellowship and A. Jordán-Pla by a FPI fellowship from the Spanish MCINN. J.E.P-O. was supported by grants from the Spanish MCINN (BFU2007-67575-C03-01 and BFU2010-21975-C03-01), and from the Regional Valencian Government (Generalitat Valenciana - ACOMP/2009/368).

\section{References}

[1] R. Parker, H. Song, The enzymes and control of eukaryotic mRNA turnover, Nat. Struct. Mol. Biol. 11 (2004) 121-127.

[2] J.E. Pérez-Ortín, J. García-Martínez, T.M. Alberola, DNA chips for yeast biotechnology. The case of wine yeasts, J. Biotechnol. 98 (2002) 227241.

[3] J. García-Martínez, A. Aranda, J.E. Pérez-Ortín, Genomic run-on evaluates transcription rates for all yeast genes and identifies gene regulatory mechanisms, Mol. Cell. 15 (2004) 303-313.

[4] V. Pelechano, J.E. Pérez-Ortín, There is a steady-state transcriptome in exponentially growing yeast cells, Yeast 27 (2010) 413-422.

[5] D.L. Bentley, M. Groudine, A block to elongation is largely responsible for decreased transcription of c-myc in differentiated HL60 cells, Nature 321 (1986) 702-706.

[6] B. Ren, F. Robert, J.J. Wyrick, O. Aparicio, E.G. Jennings, I. Simon, J. Zeitlinger, J. Schreiber, N. Hannett, E. Kanin, T.L. Volkert, C.J. Wilson, S.P. Bell, R.A. Young, Genome-wide location and function of DNA binding proteins, Science 290 (2000) 2306-2309.

[7] L.E. Rosaleny, A.B. Ruiz-García, J. García-Martínez, J.E. Pérez-Ortín, V. Tordera, The Sas3p and Gcn5p histone acetyltransferases are recruited to similar genes, Genome. Biol. 8 (2007) R119.

[8] P. Lefrancois, G.M. Euskirchen, R.K. Auerbach, J. Rozowsky, T. Gibson, C.M. Yellman, M. Gerstein, M. Snyder, Efficient yeast ChIP-Seq using multiplex short-read DNA sequencing, BMC Genomics 10 (2009) 37.

[9] H. Kim, B. Erickson, W. Luo, D. Seward, J.H. Graber, D.D. Pollock, P.C. Megee, D.L. Bentley, Gene-specific RNA polymerase II phosphorylation and the CTD code, Nat. Struct. Mol. Biol. 17 (2010) 1279-1286.

[10] A. Mayer, M. Lidschreiber, M. Siebert, K. Leike, J. Soding, P. Cramer, Uniform transitions of the general RNA polymerase II transcription complex, Nat. Struct. Mol. Biol. 17 (2010) 1272-1278.

[11] L.S. Churchman, J.S. Weissman, Nascent transcript sequencing visualizes transcription at nucleotide resolution, Nature 469 (2011) 368-373.

[12] F. Carrillo Oesterreich, S. Preibisch, K.M. Neugebauer, Global analysis of nascent RNA reveals transcriptional pausing in terminal exons, Mol. Cell. 40 (2010) 571-581.

[13] K. Hirayoshi, J.T. Lis, Nuclear run-on assays: assessing transcription by measuring density of engaged RNA polymerases, Methods. Enzymol. 304 (1999) 351-362.

[14] V. Pelechano, S. Chávez, J.E. Pérez-Ortín, A complete set of nascent transcription rates for yeast genes, PLoS One 5 (2010) e15442.

[15] M.M. Molina-Navarro, L. Castells-Roca, G. Bellí, J. García-Martínez, J. Marín-Navarro, J. Moreno, J.E. Pérez-Ortín, E. Herrero, Comprehensive transcriptional analysis of the oxidative response in yeast, J. Biol. Chem. 283 (2008) 17908-17918.

[16] L. Romero-Santacreu, J. Moreno, J.E. Pérez-Ortín, P. Alepuz, Specific and global regulation of mRNA stability during osmotic stress in Saccharomyces cerevisiae, RNA 15 (2009) 1110-1120.

[17] L.J. Core, J.J. Waterfall, J.T. Lis, Nascent RNA sequencing reveals widespread pausing and divergent initiation at human promoters, Science 322 (2008) 1845-1848

[18] J. Fan, K. Zeller, Y.C. Chen, T. Watkins, K.C. Barnes, K.G. Becker, C.V. Dang, C. Cheadle, Time-dependent c-Myc transactomes mapped by Arraybased nuclear run-on reveal transcriptional modules in human B cells, PLoS One 5 (2010) e9691.

[19] M. Ohtsu, M. Kawate, M. Fukuoka, W. Gunji, F. Hanaoka, T. Utsugi, F. Onoda, Y. Murakami, Novel DNA microarray system for analysis of nascent mRNAs, DNA. Res. 15 (2008) 241-251.

[20] M.D. Cleary, C.D. Meiering, E. Jan, R. Guymon, J.C. Boothroyd, Biosynthetic labeling of RNA with uracil phosphoribosyltransferase allows cell-specific microarray analysis of mRNA synthesis and decay, Nat. Biotechnol. 23 (2005) 232-237.

[21] M. Kenzelmann, S. Maertens, M. Hergenhahn, S. Kueffer, A. HotzWagenblatt, L. Li, S. Wang, C. Ittrich, T. Lemberger, R. Arribas, S. Jonnakuty, M.C. Hollstein, W. Schmid, N. Gretz, H.J. Grone, G. Schutz, Microarray analysis of newly synthesized RNA in cells and animals, Proc. Natl. Acad. Sci. U S A. 104 (2007) 6164-6169.

[22] F.C. Holstege, E.G. Jennings, J.J. Wyrick, T.I. Lee, C.J. Hengartner, M.R. Green, T.R. Golub, E.S. Lander, R.A. Young, Dissecting the regulatory circuitry of a eukaryotic genome, Cell 95 (1998) 717-728. 
[23] F. Robert, D.K. Pokholok, N.M. Hannett, N.J. Rinaldi, M. Chandy, A. Rolfe, J.L. Workman, D.K. Gifford, R.A. Young, Global position and recruitment of HATs and HDACs in the yeast genome, Mol. Cell. 16 (2004) 199-209.

[24] D.K. Pokholok, C.T. Harbison, S. Levine, M. Cole, N.M. Hannett, T.I. Lee, G.W. Bell, K. Walker, P.A. Rolfe, E. Herbolsheimer, J. Zeitlinger, F. Lewitter, D.K. Gifford, R.A. Young, Genome-wide map of nucleosome acetylation and methylation in yeast, Cell 122 (2005) 517-527.

[25] Z. Xu, W. Wei, J. Gagneur, F. Perocchi, S. Clauder-Munster, J. Camblong, E. Guffanti, F. Stutz, W. Huber, L.M. Steinmetz, Bidirectional promoters generate pervasive transcription in yeast, Nature 457 (2009) 1033-1037.

[26] J. Berretta, A. Morillon, Pervasive transcription constitutes a new level of eukaryotic genome regulation, EMBO. Rep. 10 (2009) 973-982.

[27] R. Parker, D. Herrick, S.W. Peltz, A. Jacobson, Measurement of mRNA decay rates in Saccharomyces cerevisiae, Methods. Enzymol. 194 (1991) 415-423.

[28] P. Sunnerhagen, Cytoplasmatic post-transcriptional regulation and intracellular signalling, Mol. Genet. Genomics. 277 (2007) 341-355.

[29] Y. Wang, C.L. Liu, J.D. Storey, R.J. Tibshirani, D. Herschlag, P.O. Brown, Precision and functional specificity in mRNA decay, Proc. Natl. Acad. Sci. U S A. 99 (2002) 5860-5865.

[30] J. Grigull, S. Mnaimneh, J. Pootoolal, M.D. Robinson, T.R. Hughes, Genome-wide analysis of mRNA stability using transcription inhibitors and microarrays reveals posttranscriptional control of ribosome biogenesis factors, Mol. Cell. Biol. 24 (2004) 5534-5547.

[31] C.C. Friedel, L. Dolken, Metabolic tagging and purification of nascent RNA: implications for transcriptomics, Mol. Biosyst. 5 (2009) 1271-1278.

[32] C. Miller, B. Schwalb, K. Maier, D. Schulz, S. Dumcke, B. Zacher, A. Mayer J. Sydow, L. Marcinowski, L. Dolken, D.E. Martin, A. Tresch, P. Cramer, Dynamic transcriptome analysis measures rates of mRNA synthesis and decay in yeast, Mol. Syst. Biol. 7 (2011) 458.

[33] J.E. Pérez-Ortín, P.M. Alepuz, J. Moreno, Genomics and gene transcription kinetics in yeast, Trends. Genet. 23 (2007) 250-257.

[34] L. Castells-Roca, J. García-Martínez, J. Moreno, E. Herrero, G. Bellí, J.E. Pérez-Ortín, Heat shock response in yeast involves changes in both transcription rates and mRNA stabilities, PLoS One 6 (2011) e17272.

[35] T.S. Kim, C.L. Liu, M. Yassour, J. Holik, N. Friedman, S. Buratowski, O.J. Rando, RNA polymerase mapping during stress responses reveals widespread nonproductive transcription in yeast, Genome. Biol. 11 (2010) R75.

[36] M. Yassour, J. Pfiffner, J.Z. Levin, X. Adiconis, A. Gnirke, C. Nusbaum, D.A. Thompson, N. Friedman, A. Regev, Strand-specific RNA sequencing reveals extensive regulated long antisense transcripts that are conserved across yeast species, Genome. Biol. 11 (2010) R87.

[37] D. Zenklusen, D.R. Larson, R.H. Singer, Single-RNA counting reveals alternative modes of gene expression in yeast, Nat. Struct. Mol. Biol. 15 (2008) 1263-1271.
[38] L.M. Hereford, M. Rosbash, Number and distribution of polyadenylated RNA sequences in yeast, Cell 10 (1977) 453-462.

[39] M. Bon, S.J. McGowan, P.R. Cook, Many expressed genes in bacteria and yeast are transcribed only once per cell cycle, FASEB. J. 20 (2006) 1721-1723.

[40] G. Jona, M. Choder, O. Gileadi, Glucose starvation induces a drastic reduction in the rates of both transcription and degradation of mRNA in yeast, Biochim. Biophys. Acta. 1491 (2000) 37-48.

[41] O. Shalem, O. Dahan, M. Levo, M.R. Martínez, I. Furman, E. Segal, Y. Pilpel, Transient transcriptional responses to stress are generated by opposing effects of mRNA production and degradation, Mol. Syst. Biol. 4 (2008) 223.

[42] B. Hayles, S. Yellaboina, D. Wang, Comparing transcription rate and mRNA abundance as parameters for biochemical pathway and network analysis, PLoS One 5 (2010) e9908.

[43] D.J. Hogan, D.P. Riordan, A.P. Gerber, D. Herschlag, P.O. Brown, Diverse RNA-binding proteins interact with functionally related sets of RNAs, suggesting an extensive regulatory system, PLoS Biol 6 (2008) e255.

[44] J.D Keene, RNA regulons: coordination of post-transcriptional events, Nat. Rev. Genet. 8 (2007) 533-543.

[45] J. García-Martínez, F. González-Candelas, J.E. Pérez-Ortín, Common gene expression strategies revealed by genome-wide analysis in yeast, Genome. Biol. 8 (2007) R222.

[46] J. Fan, X. Yang, W. Wang, W.H. Wood 3rd., K.G. Becker, M. Gorospe, Global analysis of stress-regulated mRNA turnover by using cDNA arrays, Proc. Natl. Acad. Sci. U S A. 99 (2002) 10611-10616.

[47] M. Schuhmacher, F. Kohlhuber, M. Holzel, C. Kaiser, H. Burtscher, M. Jarsch, G.W. Bornkamm, G. Laux, A. Polack, U.H. Weidle, D. Eick, The transcriptional program of a human B cell line in response to Myc Nucleic. Acids. Res. 29 (2001) 397-406

[48] M. Meininghaus, R.D. Chapman, M. Horndasch, D. Eick, Conditional expression of RNA polymerase II in mammalian cells. Deletion of the carboxyl-terminal domain of the large subunit affects early steps in transcription, J. Biol. Chem. 275 (2000) 24375-24382.

[49] C. Cheadle, J. Fan, Y.S. Cho-Chung, T. Werner, J. Ray, L. Do, M. Gorospe, K.G. Becker, Control of gene expression during $T$ cell activation: alternate regulation of mRNA transcription and mRNA stability, BMC. Genomics. 6 (2005) 75

[50] S.A. Tenenbaum, C.C. Carson, U. Atasoy, J.D. Keene, Genome-wide regulatory analysis using en masse nuclear run-ons and ribonomic profiling with autoimmune sera, Gene 317 (2003) 79-87.

[51] E.J. Steinmetz, C.L. Warren, J.N. Kuehner, B. Panbehi, A.Z. Ansari, D.A Brow, Genome-wide distribution of yeast RNA polymerase II and its control by Sen 1 helicase, Mol. Cell. 24 (2006) 735-746.

[52] V. Pelechano, J.E. Pérez-Ortín, The transcriptional inhibitor thiolutin blocks mRNA degradation in yeast, Yeast 25 (2008) 85-92. 